\title{
農薬製剂・施用法の歩みと今後の展望”
}

\author{
藤田茂 樹* \\ クミアイ化学工業株式会社製剤技術研究所
}

（2013年5月 13日受理）

\section{Recent advances and future prospects in the pesticide formulation and application technologies in Japan}

\author{
Shigeki FujITA \\ Formulation Technology Institute, Kumiai Chemical Industry Co., Ltd., \\ 100 Shibukawa, Shimizu-ku, Shizuoka-shi, Shizuoka 424-0053, Japan
}

Keywords: formulation, application, labor-saving, environmental loading, cost.

\begin{abstract}
は じめに
\footnotetext{
\#第38回大会シンポジウムを取りまとめた解説.

* 干 424-0053 静岡県静岡市清水区渋川 100

E-mail: s-hujita@kumiai-chem.co.jp

(c) 日本農薬学会
}

かつて農薬防除は「きつい」,「污い」,「危険」の3Kであっ た。さらに，近年は「高価」という認識も加わるが，農薬防 除は現代の農業にとって久くことのできない農業資材の一つ である。本来, 農薬製剤の基本的な目的は, 農薬を使用し易 い形にすること，つまり少量の農薬有効成分を広範囲に，か つ，均一に散布することができる形態にすることである。し かし，それ以外にも農薬製片に期待されることは多く, 農薬 の効果を最大限発揮させること, 農薬の短所をカバーするこ と, 使用者の安全性, 環境安全性を付与すること, 農薬散布 の作業性を改善したり省力化を図ること等が挙げられる。一 方, 農耕地の面積の減少, 農業従事者の高齢化, 専業農家の 減少, 残留農薬に対する社会的な関心の高まり, ポジティブ リスト制度の施行等, 時代によって農薬を取り巻く環境は変
化をしており, 特に近年, これらの変化を考慮した農薬製剂 の設計として,「省力化」,「環境負荷」が重要なキーワードで ある。また，これらのキーワードを踏まえた農薬製剤は高付 加価值製剤であり，一般的に原料や製造経費も高くなる傾向 にあるため「低コスト」も製剤設計の重要なキーワードとい

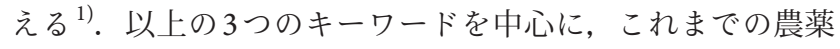
製剂と施用法の歩みと今後の展望について述べる.

\section{1. 省力化}

水稲栽培を例にとると, 除草作業に要する時間は, 優れ た除草剤の普及により 1950 年から 40 年の間に $1 / 20$ となった が, 市場にはさらなる省力化の要求がある. その要因とし て, 使用者が高齢化していること, 専業農家が減少している こと, 一方, 区画整理により大規模围場の増大が進んでいる こと等が挙げられ，それに対するが農薬散布の省力化を具現 化する手段として,「軽量化 (少量製剂)」「省力化製剂」「散 布装置の利用」等がある.

\section{1. 軽量化（少量製剂）}

かつて, 農薬製剂の使用量は $10 \mathrm{a}$ 当たり $3 \mathrm{~kg}$ を処理してい 
たが，1994年に 1 キロ粒剂が普及し始め, 水田に持ち込む農 薬粒剂の量は物量的に $1 / 3$ に減少した。それに伴い，粒剤の 散布機も 1 キロ粒剤対応型に改良され，1度農薬をタンクに 入れれば，従来の3倍の面積を処理することが可能となり， 大きな水田であっても，車まで戻って農薬を詰め替える労力 が減ることとなった。この1キロ粒剂には，処理量が $1 / 3$ に なっても十分な防除効果が得られる製剂技術として，十分な 散布到達性や，成分の拡散性が良好となる技術が用いられて いる.

また，次項の省力化製剂で述べるが，1990年台中頃から 普及し始めた $10 \mathrm{a}$ 当たり $250 \sim 500 \mathrm{~g}$ を散布するジャンボ剂 やフロアブル剂といった省力化製剤も軽量化に大きく貢献す ることとなった。

\section{2. 省力化製剤}

省力化製剤は，水という拡散媒体がある水稲分野が主な対 象であり，水田に入らずに畦畔から散布することをコンセプ トに開発，普及した製郕である。製剤技術が最も反映される 農薬製剂と言える，以下に主な製剤について述べる ${ }^{2)}$.

フロアブル剂は元々水に希䣋して散布されていた製剤であ るが，水田に直接散布されるようになった。容器の口の部分 に数個の穴が開いた中栓があり，そこから中身が飛び出る構 造となっており，畦畔を回りながら $10 \mathrm{a}$ 当たり $500 \mathrm{~mL}$ の製 剂を数十回に分けて振り込むように散布する。この製剤には 原液のまま液滴の状態で散布されても，成分が均一に拡散す るような製剤技術が用いられている（図1）.

ジャンボ剤はポリビニルアルコール等の水溶性フィルムの 中に拡散型粒剤や浮遊型粒剂が 1 袋当たり $25 \sim 50 \mathrm{~g}$ 入った製 剂が主流であり，そのほかに入浴剤のように炭酸がスを発す る成分を固めた製剤もあるが，いずれも $10 \mathrm{a}$ 当たり 10 個を 水田に投げ入れる製剤であり，非常に省力的な散布が可能な 製剤である．他の省力製剤と比べて極めて局所的な処理とな るため, 成分の拡散性が最も要求される製剤であり，成分の

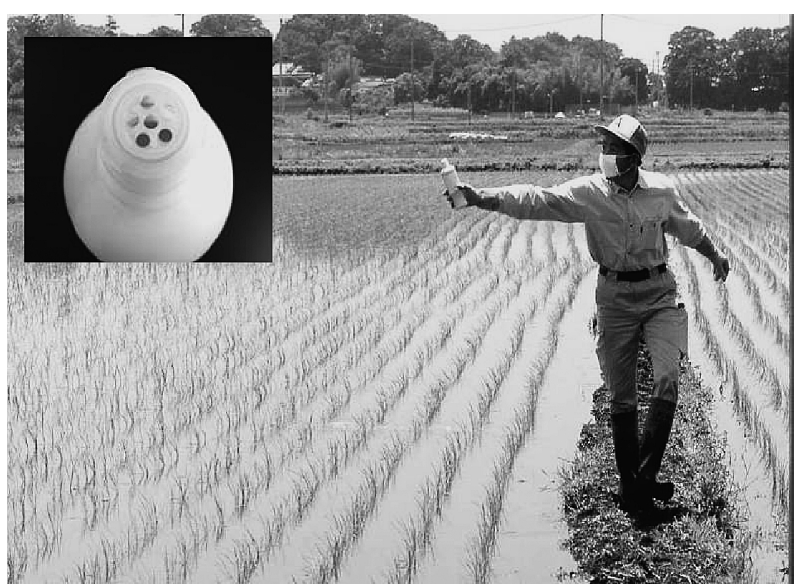

図1.フロアブル散布

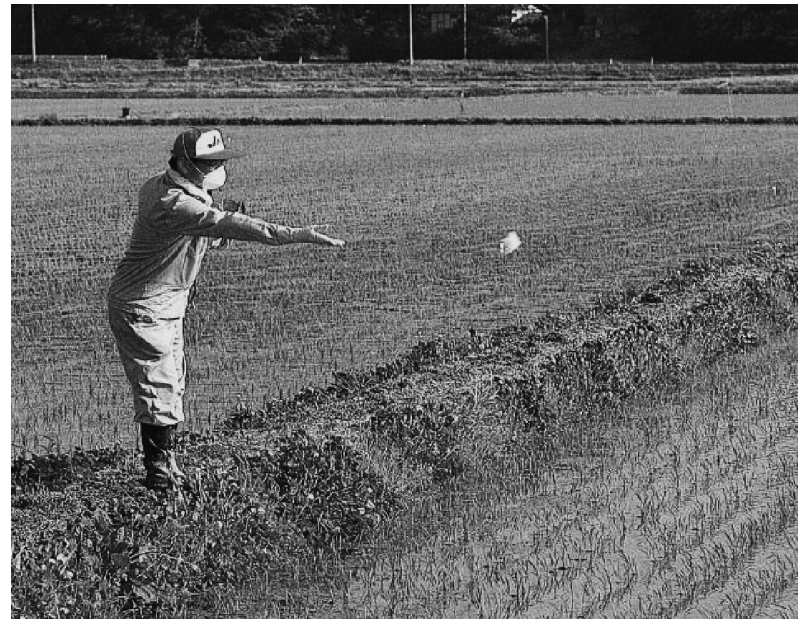

図2.ジャンボ剤の散布

拡散距離を評価するモデル試験等によって製剤の最適化が図 られ製品化されている(図2).

豆つぶ®阂は粒径が約 $5 \mathrm{~mm}$ と通常の粒剤より粒が大きな 製剤であり，10 a 当たり $250 \mathrm{~g}$ を施用する，散布すると水面 に浮き，短時間で崩壊し水田全体に拡散する，1粒が大きい ため，遠くまで投げ入れることができることが特徴であり， 畦畔を歩きながら手に掴んでばら撒いたり，釣りのコマセを 撒く柄构でさらに遠くまで散布することができるが, 動力散 布機やラジコンへリ散布等の散布装置を用いることで，より 省力的な散布も可能である. 水田の規模によって好みの方法 で散布することが可能な製剤と言える（図3）。この製郕は、 水面に浮くための微細な中空体を含有し，また，水面，すな わち水と空気の界面において, 短時間で崩壊させることに最 適化した組成となっている2,3).

\section{3. 散布装置の利用}

農薬散布の省力化には専用の散布装置を用いる方向性もあ る. 水稲を例に挙げると, 種子消毒として吹付処理装置, 育 苗箱への播種時処理装置, 田植え同時薬剤処理装置, 移植後 に農薬を散布する装置として, 動力散布機, ラジコンヘリ散 布装置等，種々の装置が用いられ，省力化が図られている. また，農薬が処理される時期は，田植え後よりも田植え時， 田植え時よりも育苗期, 育苗期よりも種子というょうに, 稲 の栽培ステージ前である程処理する面積が少なく, 効率的で ある．農薬製剤だけでなく農薬の施用技術も時代によって進 化していると言える.

ところで，これらの散布装置は薬剂に対して必ずしも万能 ではなく，装置に適合した農薬製凨が必要である。例えば, 種子消毒における吹付処理では, 高濃度の農薬希釈液が処理 されるが, 装置の配管の中を高濃度の希釈液か数日間満たさ れるため, 液の流れがない部分に固形分が詰まりやすくな る，高濃度薬液を処理する装置においては，それがない製剤 


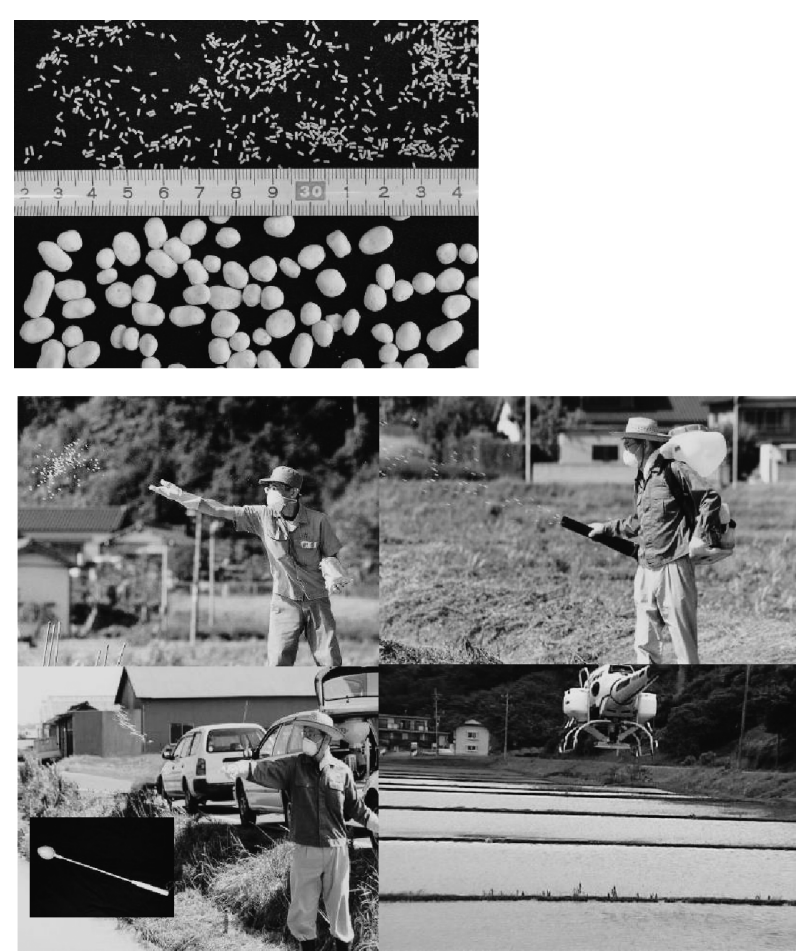

図3. 豆つぶ®剂とその散布

が要求される。また，育苗箱への播種時処理では，発芽時の 最もデリケートなときに薬剤と接触するため薬害が生じやす く，それがない製剤であることが要求される，また，装置の 中で粒剂が潰れない硬度，また，時間当たりょり沢山の育苗 箱に施用できる繰り出し量を確保できるあることも製剤の要 件である．田植え同時処理では，移植直後の稲の根は土壌に 深く埋め込まれているわけではないため薬剤の影響を受けや すく，薬害を抑制した製郕が必要である．田植え後の水田に 動力散布機を用いて粒剂を畦畔から散布する場合，動力散布 機に装着した単管噴頭でより遠くまで飛ばすための製剤設計 が必要である．ラジコンへリで薬液を空中散布する場合，原 則的には希釈散布ではあるが，地上散布と異なり，機体への 搭載量の都合から，8倍や16倍といった非常に高濃度の希釈 液が散布される，農薬製剂にはこの希釈に耐えられる希釈性 能，および高濃度希釈液のノズルからのスプレーに影響のな い性質が要求される。また，ラジコンへリ散布は 1 㓮だけで 散布するのは不経済であるため, 同時に複数の薬剂が散布さ れる場面が多く，薬剤同士を混合しても凝集等の問題がない 混用性も要求される.

以上のように，散布装置への製剤適性として，製剤技術が 担う部分は非常に多い.

\section{2. 環境負荷軽減 ${ }^{2)}$}

現代の農薬は非常に安全性の高いものであるが, 化学物質 であることに変わりはなく, 社会通念上, 人畜あるいは自然
環境に対して何らかの影響を及ぼすとの認識を払拭すること はできない化学製品である.このような製品を取り巻く現代 の社会環境として，2006年にはポジティブリスト制度が施 行され, 未登録作物に対し一律 $0.01 \mathrm{ppm} と い う$ 厳しい作物 残留基準值か設けられた。 また，流通面からは，農林水産省 が定めたガイドラインに従って生産された特別栽培農産物 は，付加価值が高まることが実態である。農薬を化学物資と して認識し, 取り扱う上では, 環境負荷軽減は現代の農薬に 求められる一つの方向性と言える.

\section{1. ドリフト軽減}

粒子は小さな粒子ほど飛散しやすく，農薬製剂を散布する 際のドリフトの原因となっている. 1950年以降, 主に水稲 栽培の中後期の製剤として, 直接散布剤である粉剤が普及し たが，散布時のドリフトが著しく，1970年以降ドリフト軽 減の取組みが行われた。その中で確立されたのが飛散し易い 微粒子を取り除き，凝集剂を配合して見掛け上の粒子を大き くした DL粉剤と，63２12 ミクロンという散布剤としては

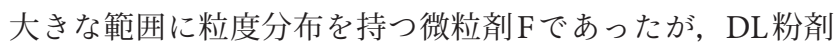
は安価に生産ができること，また，当時の基準で粉剤のドリ フト軽減の基準が達成できたことから, 次第に微粒剤 $\mathrm{F}$ はな くなり，DL粉剂が広く普及することとなった。しかし，DL 粉剤のドリフトは，ポジティブリストが施行された現代の基 準で容認できるものではなく, 2006年に日本植物防疫協会 が主体となって微粒剂協議会が発足し, 微粒剂 $\mathrm{F}$ が現代に廷 ることとなった．現在はまだ数剤が登録を受けているのみで あるが，今後さらなる普及が期待される製剤である．（図4）

\section{2. 生物農薬}

生物農薬は，天然物素材を利用した農薬である。農薬登録 は当然必要であるが，元々自然界に存在している素材である ため, 農薬としてのカウントはゼロである.1990年代の終 わり頃から普及し始め, 急激に使用量が増えているわけでは ないものの, 生産金額は現在も増加傾向にある．生物農薬は 然るべき評価を経て農薬登録となるが，単に施用すればよい のはなく, 化学農薬並の活性を得るには最適な施用条件が必 要であること, また, 生物農薬の多くは胞子や芽胞といった 耐久体が有効成分ではあるが, 生き物であるため貯蔵時の安 定性が化学農薬と比べて劣る問題点を内在している.

\section{3. 生物農薬と化学農薬のハイブリッド農薬}

生物農薬と化学農薬を混合したハイブリッド型農薬も近年 普及を始めた。化学農薬の部分はカウントされるが, 生物農 薬と併用することにより, 化学農薬の薬量の低減が可能とな ること, また, 適用範囲の拡大, 化学農薬の抵抗性回避等, 種々のメリットが期待される. 

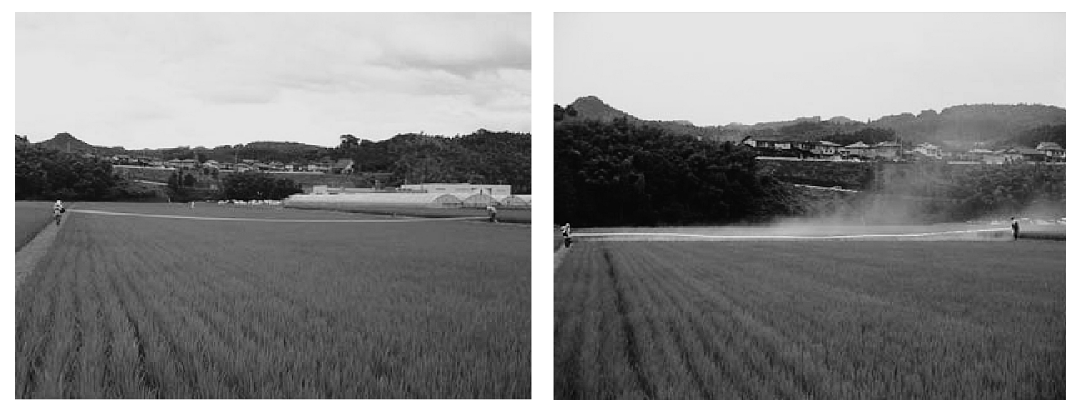

図4. 微粒剂 FとDL粉剂の散布

\section{3. 低コスト ${ }^{1)}$}

農業経営における経費の内，農薬に占める割合は，例えば 稲作農家において1割弱程度であるが，心情的には少しでも 低減したい経費と言える，安価な農薬を提供するには農薬製 剤自体のコストを低減する必要があるが，昨今の農薬は付加 価值の高い製剂が求められることが多く，それが農薬製剤の 原価に反映することとなる。それに対し，農薬製郕メーカー は様々な角度からコスト低減を図っている。

例えば，製剤コストの低減に関して，生産の効率化は重要 な課題である. 実験室で目的とする製郕が得られたとして も，それが実際の工場で効率的に生産できなければコストの 高い製剂となるため，想定される生産設備を見据え，製剤検 討の初期の段階から，工場での効率的な生産を視野に入れて 製剤検討を行うことが必要である。

ところで，農薬製剤の原価に占める割合が最も大きいのは 農薬の有効成分である，単位重量当たりの価格が同じ有効成 分であるならば，高活性な化合物ほど使用量は少なくて済む ことから，このような有効成分を用いることは農薬価格の低 減に有効である。また，使用量が少ないことは単位面積当た りに投下される化学物質の量が少ないことであることから， 環境負荷低減からも好ましい，近年開発される農薬の有効成 分はほとんどが高活性な物質であり, 農薬製剤の歩みと平行 した農薬開発の一つの方向性と言える.

\section{4. 今後の展望}

以上，3つのキーワードに関し，個々に農薬製剤の視点か ら述べてきたが，いずれのキーワードにも関わる概念とし て，農薬成分の効率的な利用を挙げることができる。これ は，PDS (Pestiside Derivery System)という概念であり，必 要な時に, 必要な場所に, 必要な量だけ有効成分を送り届け るということである ${ }^{4)}$. 具体的な技術の一つとして溶出制御 が挙げられる，例えば，水田の水面施用剤に扔いては，薬害 が発生する水中濃度に達することなく, 効果発現に必要な濃 度だけを長期間維持させる制御技術であれば処理薬量の低

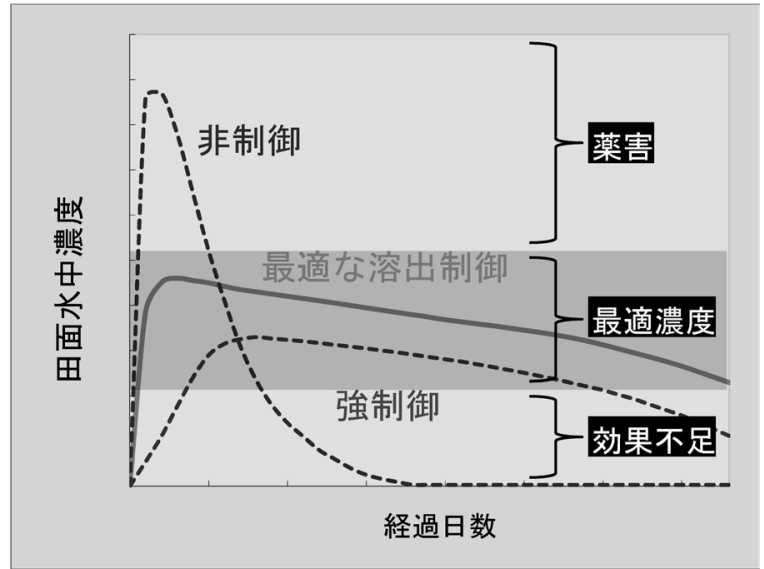

図5. 水面施用剂の溶出

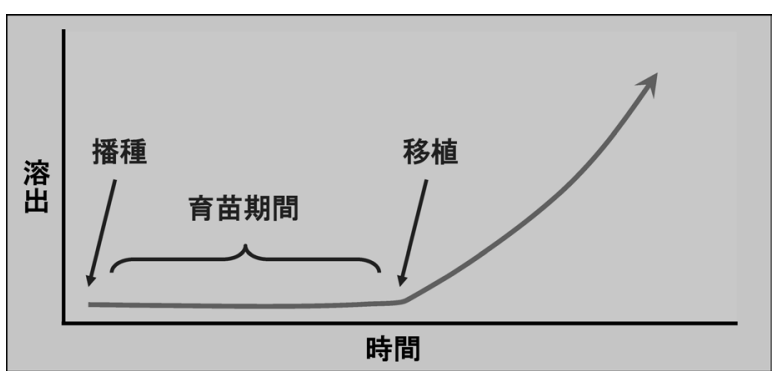

図6. 水稲育苗箱播種時処理剤の溶出

減，散布回数の低減が実現できる ${ }^{2)}$ (図 5)。また，播種時処 理用の育苗箱処理剤においては, 薬剤の効果が不要な育苗期 間は有効成分を製剤中に閉じ込めておき，水田に移植された 後溶出する制御技術であれば薬害がなく処理薬量の低減を実 現することができる（図6）。現在，これらの製剤技術はあ る程度のレベルまで達しているが, 今後, 制御の精度を高め ることで, さらに無駄のない農薬の利用が可能となり, 省力 化，環境負荷低減，低コストに繋げることができるととも に，時代に即した新たな効果も期待することができると考え られる。

また，農薬製剂はこれまで施用法と共に歩んできた一面が あり, 今後も農薬製剤の性能を最大限発揮するための様々な 
施用法, 及び散布装置に適合する使用しやすい製剂を目指し てしていきたい。

\section{引用文 献}

1) 大川哲生：農薬製剤・施用法シンポジウム第 30 回大会講演要旨 集, pp. 15-17 (2010).

2) 藤田茂樹：農林水産技術研究ジャーナル 34(11), 32-36 (2011).

3）藤田茂樹, 加藤進: 農林水産技術研究ジャーナル 34(3), 21-24 (2011).

4）辻孝三: 農薬製剤はやわかり, 化学工業日報社, p. 173 (2006).

略 歴

藤田茂樹（ふじた しげき）

生年月日：1959年11月13日

最終学歴: 静岡大学農学部農芸化学科

研究テーマ: 農薬製剂研究

趣味：街道歩き, 自転車, 溪流釣り 